\title{
DESAIN PEMBELAJARAN BANGUN DATAR MELALUI PENDEKATAN REALISTIC MATHEMATICS EDUCATION
}

\section{(TWO-DIMENTIONAL FIGURE LEARNING DESIGN THROUGH A REALISTIC MATHEMATICS EDUCATION APPROACH)}

\author{
Ratna Hadila ${ }^{1}$, Sukirwan ${ }^{2}$, Trian Pamungkas Alamsyah ${ }^{3}$ \\ ${ }^{1}$ Program Studi PGSD UNTIRTA, ratnahadilaaa@gmail.com \\ ${ }^{2}$ Program Studi PGSD UNTIRTA, sukirwan@untirta.ac.id \\ ${ }^{3}$ Program Studi PGSD UNTIRTA, trian@untirta.ac.id
}

\begin{abstract}
Abstrak
Tujuan penelitian ini adalah untuk menggetahui desain pembelajaran bangun datar melalui pendekatan Realistic Mathematics Education (RME). Metode penelitian ini menggunakan metode desain reseach untuk menggetahui bagaiamana pendekatan RME dapat mendukung pemahaman siswa mengenai pengukuran luas. Teknik pengumpulan data menggunakan wawancara, observasi, tes dan dokumentasi. Hasil analisis diketahui bahwa dengan menggunakan kegiatan membandingkan, menggambar dan menghitung dapat membantu siswa mengembangkan pemahamannya mengenai konsep konservasi luas. Konsep ini dapat membantu siswa memahami pengertian luas dan pengukuran luas. Hal ini dimungkinkan bahwa dengan menggunakan pendekatan RME dapat membantu siswa memahami konsep konservasi luas dapat membantu siswa mengukur luas persegi dan persegi panjang dengan mengubah bentuknya dan dapat menemukan luas tanpa mengunakan rumus.
\end{abstract}

Kata Kunci: Pengukuran luas, Realistic Mathematic Education (RME), Design Research.

\begin{abstract}
The purpose of this study was to find out two-dimentional figure learning design through a Realistic Mathematics Education (RME) approach.. This research method was a research design methods, to find out how to access RME that can support students' understanding of broad measurement. Data collection techniques using interviews, observation, tests and documentation. The results of the analysis are obtained by using a comparison, drawing and calculating program that helps students develop an understanding of broad conservation concepts. This concept can help students understand broad understanding and broad measurement. This can be done by using RME funds to help students understand the concept of area to help students measure area and rectangle by changing their shape and being able to find area without using a formula.
\end{abstract}


Keywords: Area Measurement, Realistic Mathematics Education (RME), Research Design.

\section{PENDAHULUAN}

Matematika merupakan pembelajaran yang selalu berkaitan dengan angkaangka dan dianggap sulit oleh sebagian siswa. Matematika dipelajari karena dianggap sangat penting bagi kehidupan manusia. Menurut (Sumami, 2016: 26) Salah satu karakteristik matematika adalah mempunyai obyek yang bersifat abstrak. Sifat obyek matematika yang abstrak pada umumnya membuat materi matematika sulit ditangkap dan dipahami. Mengingat bahwa obyek dalam matematika bersifat abstrak, maka diperlukan model atau pendekatan yang tepat untuk menjembatani proses pembelajaran matematika, sehingga materi matematika mudah dipahami oleh siswa. Salah satu ruang lingkup pengajaran matematika yaitu geometri, termasuk didalamnya terdapat materi bangun datar.

Kemudian, Lisnani, Ilma dan Somakim (2013) mengungkapkan bahwa menurut Hiele dalam pembelajaran konsep geometri menegasakan bahwa untuk mengembangkan geometri thinking harus melalui tahapan-tahapan aktivitas yang di mulai dari permainan. Hal ini sejalan dengan Pendekatan RME dalam pelaksanaan kegiatan pembelajaran matematika melalui permainan, cerita rakyat, dan bentuk formal matematika yang biasa digunakan sebagai konteks atau masalah realistic, sehingga memotivasi siswa untuk belajar matematika terutara materi geometri bangun datar dalam menentukan luas peregi dan persegi panjang dan menciptakan suasana belajar yang menyenangkan.

Pembelajaran geometri di sekolah dasar sangat mudah untuk diaplikasikan kedalam kehidupan sehari-hari siswa karena banyak benda-benda di lingkungan sekitar yang berhubungan dengan bangun datar. Selama ini matematika yang dipelajari oleh siswa disekolah diperoleh memalalui kegiatan ceramah dan cendrung menggunakan model pembelajaran konvensional yang mengakibatkan siswa tidak aktif atau pasif hanya mendengarkan, kegiatan tersebut yang menyebabkan siswa sulit untuk menentukan luas daerah persegi dan persegi panjang, sehingga sebagian siswa kurang memahami materi dengan baik apa yang telah disampaikan dan menganggap matematika merupakan mata pelajaran yang sulit. Untuk itu perlunya meningkatkan pemahaman siswa dengan menggunakan pendekatan RME. Pendekatan RME merupakan salah satu pendekatan pembelajaran matematika yang berorientasi pada matematisasi pengalaman sehari-hari dan menerapkan matematika dalam kehidupan sehari-hari. (Fitri dan Sri, 2014: 3), hal tersebut sangat cocok diaplikasikan kedalam materi bangun datar khususnya dalam menentukan luas daerah persegi dan persegi panjang, karena materi tersebut sangat mudah diaplikasikan kedalam kehidupan sehari-hari siswa dan banyak benda-benda di lingkungan sekitar yang berhubungan dengan geometri.

Berdasarkan permasalahan diatas untuk meningkatkan pemahaman matematis siswa mengenai materi bangun datar dalam menentukan luas daerah persegi dan persegi panjang yaitu dengan menerapkan pendekatan pembelajaran kedalam proses pembelajaran yang berpengaruh kepada pemahaman matematis siswa, yaitu dengan menggunakan pendekatan RME, melalui pendekatan RME tujuannya diharapkan siswa dapat lebih memahami dan menguasai materi bangun 
datar dalam menentuka luas persegi dan persegi panjang, kemudian dapat meningkatkan kreatifitas siswa dalam menerapkan pemahaman tentang bangun datar dikehidupan sehari-hari serta dapat meningkatkan motivasi dan minat siswa dalam belajar matematika. Dari permasalah di atas peneliti tertarik untuk melakukan penelitian yang berjudul Desain Pembelajaran Bangun Datar Melalui Pendekatan Realistic Mathematics Education (RME) di Kelas IV SDN Simpang 3 Cilegon sebagai pendekatan pembelajaran yang akan digunakan dalam kegiatan belajar mengajar.

\section{KAJIAN TEORI \\ Bangun Datar}

Bangun datar dapat didefinisikan sebagai bangun yang rata yang mempunyai dua dimensi yaitu panjang dan lebar tetapi tidak mempunyai tinggi dan tebal. Dalam kehidupan sehari-hari mengambil contoh bangun datar tidaklah mudah. Misalkan saja kita ambil selembar kertas Houtvrij Schrijfpapier (HVS) atau kertan Koran sebagai bangun datar. Kalau benar benar diperiksa, kertas itu selain mempunyai panjang dan lebar juga kertas itu mempunyai tebal ataupun tinggi. Dengan alat ukur yang mempunyai ketelitian yang tinggi tebal kertas dapat diukur. Benda-benda dilihat dengan mata telanjang terlihat rata atau datar belum tentu memenuhi syarat untuk digolongkan sebagai bangun datar. Dengan demikian pengertian bangun datar adalah abstrak (Daitin Tarigan, 2006: 63). Pada dasarnya bangun datar merupakan kurva yang beraturan bentuknya (Kadiyo, 2007: 119).

\section{Realistic Mathematics Education (RME)}

Realistic Mathematics Education (RME) adalah pendekatan pembelajaran yang mengaitkan suatu masalah ke dunia nyata dalam kehidupan sehari-hari atau lingkungan sekitar. Masalah yang digunakan sebagai awal pembelajaran haru real atau nyata supaya siswa dapat memahami sesuai dengan pengalamannya. Pendekatan RME adalah pembelajaran matematika yang memanfaatkan aktivitas siswa dalam realitas dan lingkungannya untuk mentransformasi masalah dalam kehidupan sehari-harinya ke dalam simbol dan model pemecahan masalah matematika (Andini Permana, $2016: 33$ ).

Menurut (Daitin Tarigan, 2006:4), secara garis besar RME adalah pendekatan yang orientasinya menuju kepada penalaran siswa yang bersifat realistik dan ditujukan kepada pengembangan pola pikir praktis, logis, kritis dan jujur dengan berorientasi pada penalaran matematika dalam menyelesaikan masalah. Pendekatan RME adalah pembelajaran matematika yang memanfaatkan aktivitas siswa dalam realitas dan lingkungannya untuk mentransformasi masalah dalam kehidupan sehari-harinya ke dalam simbol dan model pemecahan masalah matematika.

\section{Karakteristik Pendekatan Realistic Matematikcs Education (RME)}

Menurut Grafemeijer (dalam fitri, 2007: 13) ada 5 karakteristik pembelajaran matematika realistik, yaitu sebagai berikut:

a. Menggunakan masalah kontekstual 
Masalah konsektual berfungsi sebagai aplikasi dan sebagai titik tolak dari mana matematika yang digunakan dapat muncul. Bagaimana masalah matematika itu muncul(yang berhubungan dengan kehidupan sehari- hari).

b. Menggunakan model atau jembatan

Perhatian diarahkan kepada pengembangan model, skema, dan simbolisasi dari pada hanya mentrasfer rumus. Dengan menggunakan media pembelajaran siswa akan lebih faham dan mengerti tentang pembelajaran aritmatika sosial.

c. Mengunakan kontribusi siswa

Kontribusi yang besar pada saat proses belajar mengajar diharapkan dari konstruksi murid sendiri yang mengarahkan mereka dari metode informal ke arah metode yang lebih formal. Dalam kehidupan sehari- hari diharapkan siswa dapat membedakan pengunaan aritmatika sosial terutama pada jual beli. Contohnya: harga baju yang didiskon dengan harga baju yang tidak didiskon.

d. Interaktivitas

Negosiasi secara eksplisit, intervensi, dan evaluasi sesama murid dan guru adalah faktor penting dalam proses belajar secara konstruktif dimana strategi informal siswa digunakan sebagai jembatan untuk menncapai strategi formal. Secara berkelompok siswa diminta untuk membuat pertanyaan kemudian diminta mempresentasikan didepan kelas sedangkan kelompok yang lain menanggapinya. Disini guru bertindak sebagai fasilitator.

e. Terintegrasi dengan topik pembelajaran lainnya(bersifat holistik)

Aritmatika sosial tidak hanya terdapat pada pembelajaran matematika saja, tetapi juga terdapat pada pembelajaran yang lainnya.

\section{METODE PENELITIAN}

Metode penelitian yang digunakan pada penelitian ini yaitu Design Research. Penelitian desain research mengandung pengertian suatu kajian sistematis yang merancang, mengembangkan, dan mengevaluasi intervensi pendidikan (berupa program, strategi, bahan pembelajaran, produk dan system)sebagai solusi untuk memecahkan masalah yang kompleks dalam praktek pendidikan (Plomp \& Nieven, 2007). Pada desain research terjadi proses siklik (berulang) yaitu dari eksperimen pemikiran kemudian ke eksperimen pembelajaran dalam bentuk diagram dengan ilustrasi ide percobaan dari Gravemeijer dan Cobb (dalam Akker, 2006). Diagram alir pelaksanaan eksperimen pada desain research seperti gambar berikut ini:

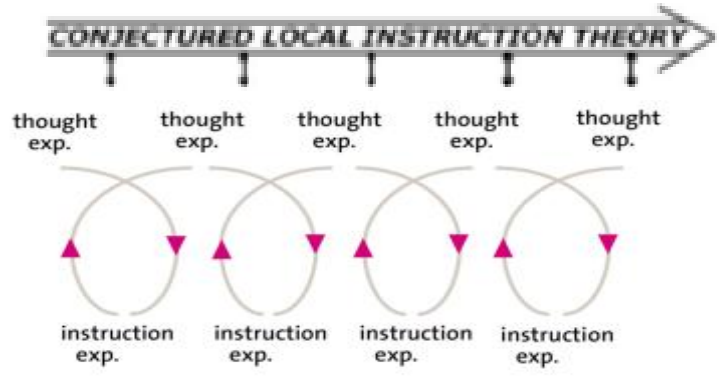

Gambar 1. Tahapan Penelitian yang dimodifikasi dari Gravemeijer \& Cobb (2006) 
Ada tiga tahap dalam jenis penelitian metode Design Research menurut (Gravemeijer and Cobb, 2006; Bakker, 2004) yaitu Preparing for the experiment, The design experiment, terdapat 2 siklus pada tahap design experiment ini yaitu Pilot experiment dan Teaching experiment, yang terakhir The retrospective analysis. Penelitian ini dilaksanakan di SDN Simpang Tiga Cilegon pada semester genap bulan Januari-Febuari tahun ajaran 2019-2020, subjek penelitian pada pilot experiment berjumlah enam orang siswa kelas IV B dan. Selanjutnya pada teaching experiment berjumlah 30 orang siswa kelas IV A. Teknik pengumpulan data berupa observasi, wawancara, tes, dan dokumentasi. Analisis data yang dikumpulkan selama fase eksperimental secara retrospektif analisis: karya siswa, catatan lapangan, dan rekaman video. Kami membandingkan siswa pembelajaran aktual dan dugaan HLT. Terkait dengan pendaftaran video, kami mendaftarkan fragmen dalam video di mana pembelajaran berlangsung, tinggalkan bagian yang tidak relevan video dan menuliskan percakapan dalam sesi wawancara dengan siswa.

\section{HASIL DAN PEMBAHASAN}

Penelitian ini menghasilkan lintasan belajar yang diperoleh melalui beberapa tahapan belajar. Hasil dari penelitian ini yaitu preparing for the experiment, siklus pertama (pilot the experiment), kemudian sebelum melaksanakan teaching experiment peneliti terlebih dahulu meningkatkan kualitas HLT yang telah dirancang sehingga diperoleh HLT yang lebih baik untuk diterapkan pada siklus kedua (Peningkatan Trajectory Pembelajaran Hipotesis), lalu siklus kedua (teaching experiment) dan restropective analysis.

\section{Observasi dan Wawancara}

Peneliti melaksanakan penlitian yang bertempat di SDN Simpang Tiga Cilegon kelas IV B sebagai kelas subjek penelitian dan IV A kelas yang bukan menjadi subjek penelitian. Pada tahap pertama peneliti melaksanakan kegiatan observasi dan wawancara di SDN Simpang Tiga Cilegon. Berdasarkan hasil observasi kegiatan belajar mengajar dikelas siswa terlihat sangat aktif dan kondusif pada jam pertama, ada beberapa siswa yang terlihat diam, kemudian ada bebrapa siswa yang berdiskusi dengan temannya dalam belajar. Lalu berdasarkan hasil wawancara dengan siswa, siswa beranggapan bahwa matematika merupakan pelajaran yang sulit, siswa juga masih mengalami kendala dalam mempelajari matematika materi bangun datar. Siswa masih kurang untuk bisa memahami materi tersebut dan materi tersebut dianggap sangat rumit.

\section{Pengajaran Awal / Pilot The Experiment (Siklus 1)}

Pada pengajaran awal pada tanggal 20 dan 24 Januari 2020 peneliti melakukan kegiatan pengajaran di kelas IV B yaitu kelas yang bukan menjadi subjek penelitian. Hanya enam siswa dari kelas IV B yang menjadi sample dari kegiatan pembelajaran. Kegiatan pembelajaran pada pilot the experimenti ini dibagi dalam dua pertemuan.

\section{a. Pengajaran Pertama}

Pada kegiatan pembelajaran pertama, siswa diminta untuk melakukan kegiatan membandingkan pecahan mata uang dan tutup tempat makan dengan ukuran yang berbeda dan bagaimana mereka memprediksi dan menentukan luas bangun datar persegi dan persegi panjang tersebut. Peneliti melakukan percobaan 
aktivitas kegiatan pembelajaran menggunkan hipotesis awal yaitu memulai dengan melihat benda-benda konkret di sekitar lingkungan. Dari hasil percobaan pengajaran pertama (Pilot The Experiment) ini akan memberikan peneliti hasil guna memperbaiki peningkatan kualitas HLT yang telah peneliti buat sebelumnya.

Lembar Aktivitas Pembelajaran 1 : "Membandingkan dua pecahan mata uang". Pada kegiatan pertama siswa melakukan aktivitas kegiatan membandingkan kedua pecahan mata uang yang memliki bentuk yang berbedabeda. Dalam masalah ini siswa tidak diperuntukan untuk mengunakan angka ataupun rumus untuk menemukan jawabannya, karena hanya berdasarkan hasil pemikiran siswa itu sendiri.

Untuk memulai pembelajaran, pertama peneliti membawa konteks pecahan mata uang dan tutup tempat makan. Peneliti menunjukan gambar uang kertas dan tutup tempat makan, kemudian meminta siswa untuk memecahkan permasalahan yang berkaitan dengan pecahan mata uang dan tutup tempat makan. Siswa harus menentukan luas kedua pecahan mata uang dan tutup tempat makan. Setelah itu peneliti membagikan LAP 1 (membandingkan pecahan mata uang dan tutup tempat makan), peneliti membiarkan siswa nya membaca permasalahan dan bertanya kepada teman sekelompoknya mengenai permasalahan yang ada dalam LAP 1 tersebut. Sambil memberikan alat-alat yang dibutuhkan oleh siswa, peneliti mengajukan beberapa pertanyaan mengenai bagaimana mereka cara mereka menyelesaikan masalah.

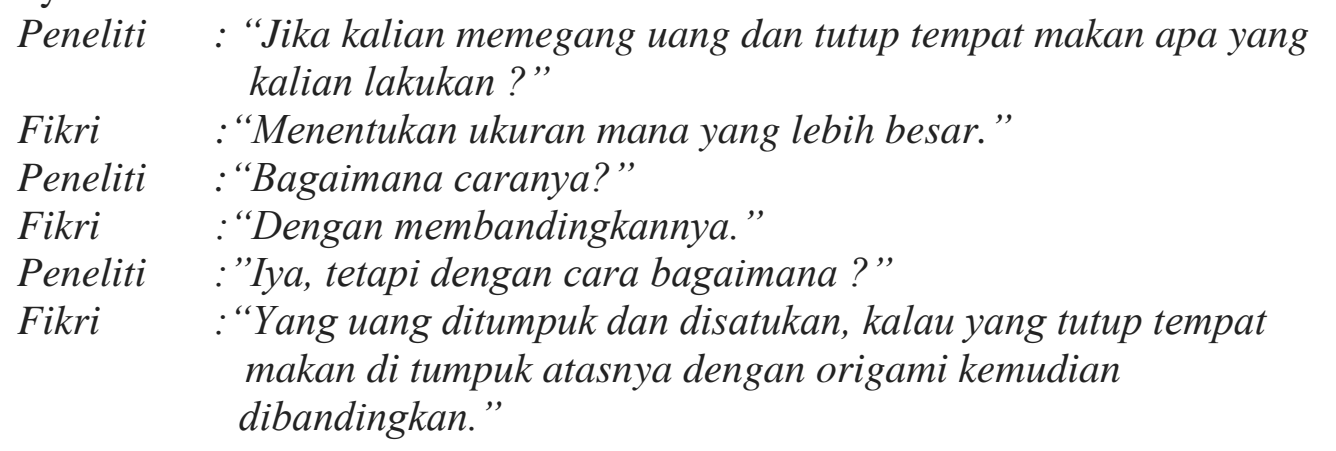

Kemudian siswa mengerjakan dengan kelompoknya, peneliti melihat bahwa siswa meletakkan uang yang satu dengan yang lainnya dengan cara di tumpuk atau tumpang tindih untuk menggetahui uang mana yang lebih besar, kemudian pada tutup tempat makan siswa melakukannya dengan cara menumpuk ketas origami ke seluruh permukan tutup tempat makan. Kelompok satu mendapatkan jawaban bahwa uang Rp. 20.000 lebih besar dibandingkan uang Rp. 5.000 dan tutup tempat makan A lebih besar dibandingkan tutup tempat makan B. Strategi tersebut sesuai dengan HLT.

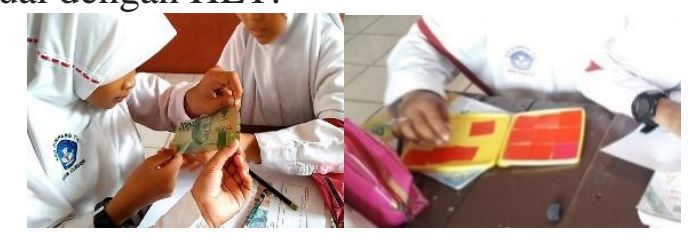

Gambar 2. Diskusi Kelompok

Mereka melakukan tumpang tindih terhadap pecahan mata uang dengan menggunakan uang saku yang mereka bawa dikantongnya, kemudian dengan tutup tempat makan mereka menggunakan kertas origami yang dipotong-potong 
dengan ukuran yang sama kemudian di tumpuk diatas permukaan tutup tempat makan hingga menutupi seluruh permukaan. Mereka sebenarnya tidak menjiplak uang dan mengguntingnya tetapi mereka langsung menggunakan uang yang mereka bawa. Peneliti tidak menduga bahwa mereka akan menggunakan uang asli. Kelompok 2 mengukur menggunakan penggaris pecahan mata uang kertas dan tutup tempat makan. Kelompok 2 memiliki solusi pemecahan masalah yang berbeda dengan kelompok 1 .

Peneliti :"Apakah kalian setuju dengan cara yang digunakan kelompok 1?"

Akmal :"Kami setuju dengan kelompok 1 karena uang B lebih besar dibanding A dan tutup tempat makan, tetapi kami tidak setuju dengan caranya."

Pebeliti :" Mengapa?"

Akmal :"Karena kami mengukur pecahan mata uang kertas dan tutup tempat makan dengan menggunakan pengaris."

Peneliti :"Mengapa anda bisa menentukan lebih besar?"

Akmal :"Karna ukurannya berbeda."
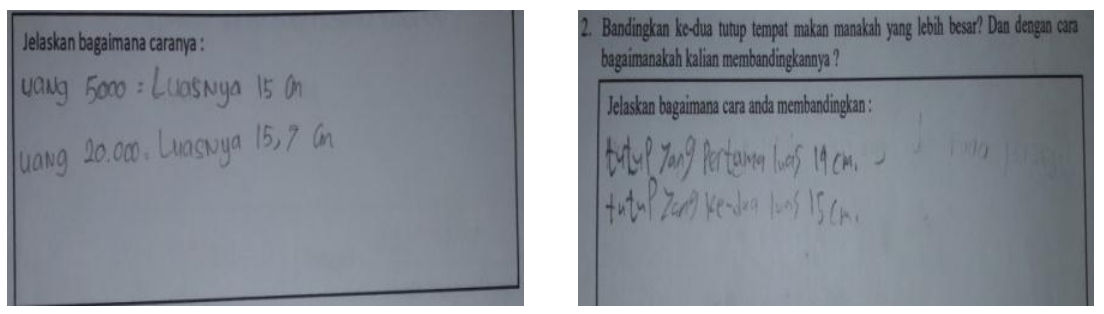

Gambar 3. Jawaban Siswa pada LAP 2

Berdasarkan percakapan di atas bahwa kelompok 1 dan 2 mempunyai ide yang berbeda dalam membandingkan pecahan mata uang kertas dan tutup tempat makan. Srtrategi kelompok 2 dengan cara mengukurnya menggunakan penggaris untuk membandingkan mana yang lebih besar. Cara atau strategi tersebut tidak sesuai dengan dugaan HLT. Kelompok 3 menyelesaikan masalah membandingkan uang pecahan kertas dan tutup tempat makan dengan cara di tempel cara seperti ini hampir sama dengan kelompok 1.

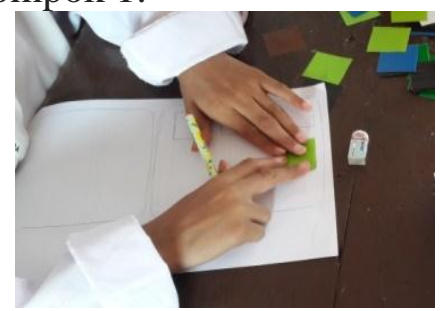

Gambar 4.Siswa Menempel Origami

Selain itu peneliti mengajukan beberapa pertanyaan dengan kelompok yang maju pada saat presentasi terkait hasil kerjanya.

(percakapan presentasi)
Peneliti
:"Bagaimana cara membandingkannya?"
Rachel : "Denga cara ditumpuk dan disatukan."
Peneliti : "Apakah ada yang berbeda cara membandingkanya?"
Rachel :"(semua siswa menggelengkan kepala)" 


\section{Peneliti : : Yang lebih besar dan luas yang mana uangnya?" \\ Rachel :" Uang Rp. 20.000."}

Pada kegiatan LAP 1 dan 2 ini siswa bisa membandingkan pecahan mata uang dan tutup tempat makan manakah yang lebih besar dengan cara ditumpuk dan disatukan menurut percakapan presentasi diatas, dan mengatakan bahwa uang Rp. 20.000 lebih besar dan luas. Dengan strategi tersebut dapat membantu mereka dalam mebandingkan pecahan mata uang dan tutup tempat makan. Kelompok 1 dan 3 menjawab LAP yang telah diberikan oleh guru sesuai dengan perdiksi atau dugaan HLT, pada kelompok 3 tidak sesuai dengan prediksi dugaan HLT.

\section{a. Pengajaran Kedua}

Pada kegiatan kedua lembar aktivitas 3, pada pertemuan kedua ini siswa akan bekerja secara individual. Siswa akan membandingkan kedua kebun teh yang tidak beraturan. Siswa harus menentukan kebun teh mana yang menghasilkan lebih banyak teh. Dalam peretemuan ini apakah siswa menyelesaikan permasalahannya dengan menggunakan cara yang sama seperti pada pertemuan pertama atau dengan strategi yang berbeda. Strategi siswa di perdiksi menggunakan HLT awal. Nikita dan Nazwa memliki jawaban yang berbeda. Bahwasannya menurut nikita kebun teh bapak andi lebih banyak menghasilkan teh dibandingkan kebun teh bapak budi begitupun sebaliknya menurut saskia. Startegi yang mereka gunakan juga berbeda dalam menyelesaikan permasalahan pada LAP 1 dan 2.
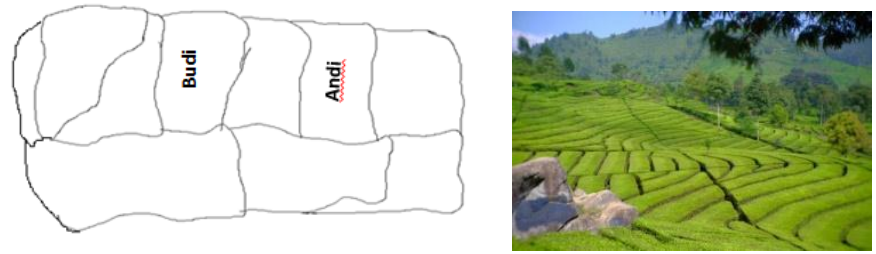

Gambar 5. Area Kebun Teh

Peneliti : "Ceritakan apa yang Anda ketahui tentang masalahnya?"

Nikita : "Menentukan kebun teh siapakah yang lebih besar."

Peneliti : "lalu, punya siapakah yang lebih besar?"

Nikita : "Bapak Andi "

Peneliti : Bagaimana cara yang anda gunakan?"

Nikita : "Bapak andi yang lebih banyak karena melihat tunas-tunas daun teh nya banyak dari pada bapak budi”

Dari percakapan diatas kita dapat menentukan bahwa nikita menggunakan startegi yang sangat berbeda dengan sebelumnya pada LAP 1 dan 2. Dalam Lap 3 ini nikita memecahkan permasalahannya hanya dengan menggunakan penilaian dangkal (penilaian persepsi) dengan hanya melihat dua area kebun teh dan mengatakan bahwa kebun teh bapak andi lebih banyak menghasilkan teh dibandingkan kebun teh bapak budi karena terlihat lebih besar atau luas.

Kemudian peneliti bertanya kembali kepada siswa yang mempunyai startegi berbeda dengan nikita yaitu saskia. Saskia membandingkan kedua kebun teh bertitik dengan cara menghitung satu per satu titik di setiap kebun teh dan membandingkannya. (lihat Gambar 5) 


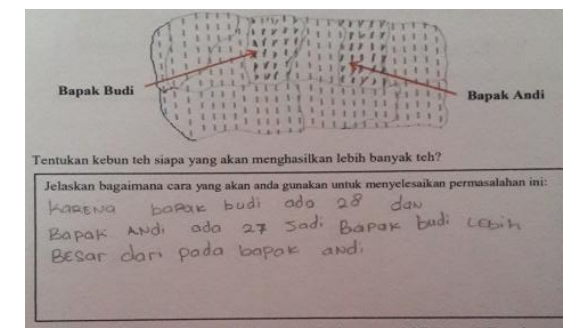

Gambar 6. Jawaban siswa pada LAP 3

Menariknya saskia menghitung satu per satu titik tersebut dengan mencoret titik-titiknya kembali dengan pensil ketika menghitung atau menentukan luas kebun teh bapak budi dan bapak andi. Saskia berfikir bahwa dengan cara begitu akan terasa lebih mudah menghitungnya. Dari hasil yang ia hitung bahwa kebun teh bapak budi lebih besar dan dapat menghasilkan lebih banyak teh dibandingkan bapak andi, karena bapak budi terdapat 28 titik dan bapak andi hanya 27 titik dibagian area kebun teh mereka. Kedua strategi yang telah dilakukan siswa pada kegiatan LAP 3 dapat membantu mereka dalam mebandingkan wilayah dua kebun teh.

\section{b. Peningkatan Trajectory Pembelajaran Hipotesis}

Berdasarkan hasil percobaan pengajaran awal, peneliti ingin meningkatkan kualitas HLT yang telah dibuat di awal. Pada tahap pilot the experiment penliti menggunakan 3 LAP yang terdiri dari LAP 1, 2 dan 3. Dan pada tahap Teaching experiment peneliti merubah semua aktivitas sehingga hanya menjadi 2 LAP saja yaitu LAP 1 dan 2. Pada tahap Teaching experiment peneliti menghilangkan kontes pecahan mata uang kertas karna dianggap bangun datar tersebut sudah terlihat ukurannya berdasarkan jumlah nominalnya yang tertera di pecahan mata uang, sehingga dikhawatirkan siswa bisa langsung menggetahui ukurannya berdasarkan melihat jumlah nominalnya. Maka dari itu kegiatan membandingkan pecahan mata uang tersebut dinilai tidak efektif.

Pada tahap teaching experiment peneliti meningkatkan kegiatan aktivitas siswa melalui tiga tahap yaitu membandingkan, menggambarkan dan menghitung. Pada kegiatan membandingkan, siswa diminta untuk menentukan area kebun teh siapa yang memiliki ukuran lebih besar. Kegiatan menggambarkan, siswa diminta untuk menggambarkan area kebun teh dan tutup tempat makan, dan menggambarkan tempelan kertas origami yang telah dibuat kelompok lain. Dan kegiatan menghitung, siswa diminta untuk bagaimana kamu cara menggetahui luas tutup tempat makan, area kebun dan bagaimana cara menghitung jumlah kertas origami yang menutupi seluruh permukaan tutup tempat makan.

\section{c. Eksperimen Mengajar / Teaching Experiment (Siklus 2)}

Dalam kegiatan eksperimen mengajar dilaksanakan pada tanggal 11 dan 12 Febuari 2020 peneliti melakukan kegiatan pengajaran di kelas IV A yaitu kelas yang Menjadi subjek penelitian. Pada bagian eksperimen mengajar, peneliti menggunakan HLT yang telah di revisi sebelumnya.

Peneliti mengamati dan menganalisis kegiatan tersebut melalui rekaman video yang dibuat pada saat peneliti mengajar. Hasil analisis Restropektif Eksperimen ini akan digunakan guna menjawab pertanyaan penelitian ini. 


\section{a) Pengajaran Pertama}

Pada kegiatan ini, siswa melakukan kegiatan membandingkan kedua tutup tempat makan dan area kebun teh. Siswa bekerja sama secara berkelompok yang berjumlah 4-5 orang. Setiap kelompok siswa harus menentukan tutup tempat makan manakah yang memiliki jumlah makanan lebih banyak dan kebun teh manakah yang menghasilkan teh lebih banyak. (Lihat pada Gambar 6). Kegiatan tersebut dapat memahami bahwa apakah dengan menggunakan strategi tumpang tindih dan menjiplak dapat menyelesaikan permasalahan pada LAP 1.

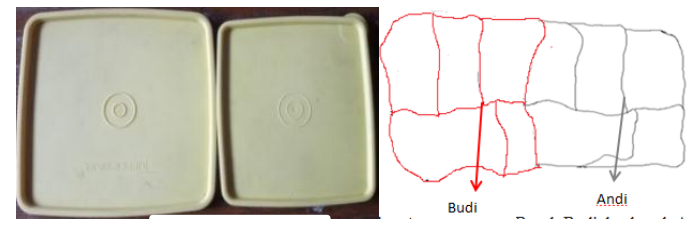

Gambar 7. Tutup tempat makan dan area kebun the

Peneliti meminta siswa untuk memahami masalah yang ada di LAP 1 dan cara apa yang akan mereka lakukan pada tutup tempat makan dan area kebun teh. Setelah itu peneliti telah menyediakan alat sepeti gunting, lem, kertas origami jika dibutuhkan siswa.

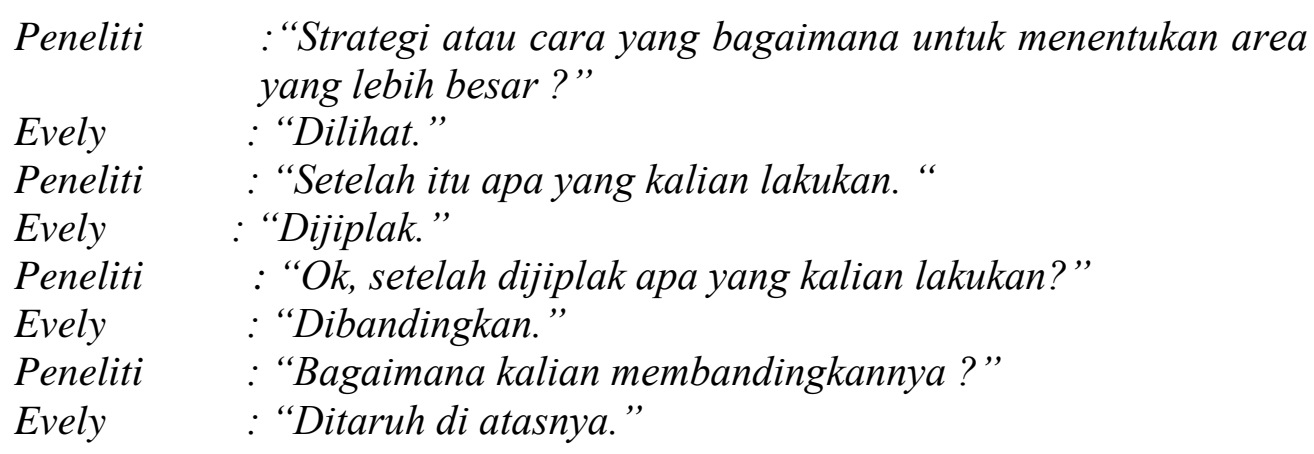

Berdasarkan percakapan di atas, siswa mempunyai strategi dengan cara tumpang tindih untuk membandingkan area kebun teh dari lembar aktivitas siswa. Siswa mengatakan bahwa mereka akan memotong kemudian membandingkannya. Oleh karena itu, peneliti menyediakan gunting, lem dan kertas. Selain itu, kelompok yang lainnya hanya menggunakan penilaian dangkal (penilaian persepsi) dengan hanya melihat kedua kebun teh tersebut dalam membandingkan kedua area kebun teh.

Setelah itu, kemudian kegiatan siswa menggambar area tanah kebun teh bapak budi dan andi, dari hasil pekerjaannya terlihat kelompok 1 terlihat jelas bahwa siswa menggambar area tanah dengan cara menjiplak. Ini sesuai dengan dugaan HLT: siswa akan menjiplak dalam menggambar kedua area kebun teh. Tetapi kelompok yang lain sebagian besarnya hanya menggunakan penilaian dangkal (penilaian persepsi) dengan melihat area kebun teh kemudian menggambarkannya.

Selanjutnya dalam kegiatan memecahkan masalah mengenai tutup tempat makan siswa diminta untuk bagaimana menggambar kedua tutup tempat makan anak bapak budi dan bapak andi, siswa memecahkan permasalahannya menggunakan strategi menjiplak sama seperti yang digunakan untuk 
memecahkan masalah kebun teh. Hal ini sesuai dengan dugaan HLT. mengerjakan LAP 1.

Kegiatan selanjutnya siswa diminta untuk bagaimana menggetahui luas kedua tutup tempat makan tersebut. Sekelompok siswa terdapat menggunakan strategi yang digunakan siswa untuk menggetahui luas kedua tutup tempat makan yaitu dengan cara mengukurnya dengan menggunakan penggaris. Hal tersebut terlihat dari hasil kerjanya. Gambar berikut ini menunjukan hasil kerja siswa.
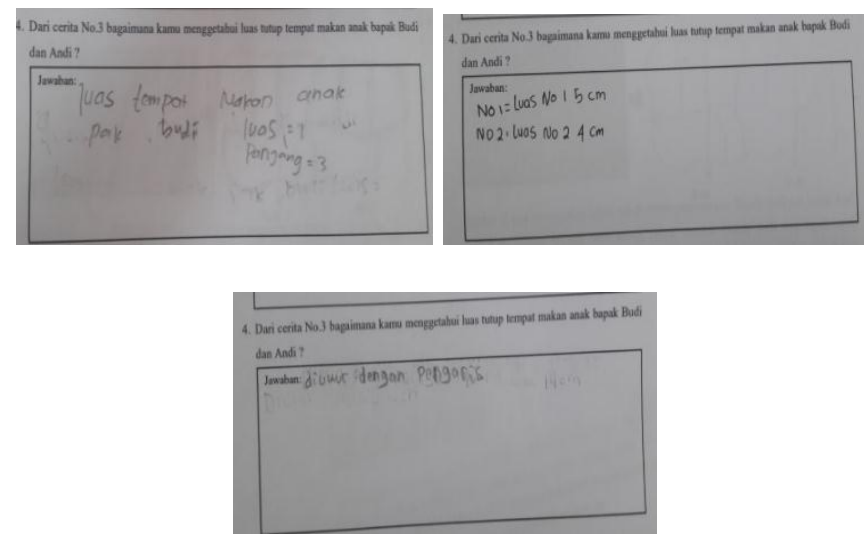

Gambar 8. Hasil Kerja Siswa

Dari Gambar 8 terlihat bahwa jawaban siswa sangat beragam, ada yang hanya menjawab dengan menuliskan "diukur menggunakan penggaris" dan ada yang menghitung luasnya dengan cara mengukur telebih dahulu menggunakan penggaris. Jawaban tersebut tidak sesuai dengan dugaan HLT karena dugaan peneliti yaitu bisa menggunakan cara tumpang tindih ataupun menjiplak. Pada kegiatan LAP 1 ini siswa dapat membandingkan dan menggambarkan area kebun teh dan tutup tempat makan manakah yang lebih besar, mereka menemukan dengan cara tumpang tindih dan mengukur menggunakan penggaris. Dengan strategi tersebut dapat membantu mereka dalam mebandingkan dan menggambarkan kedua area kebun teh dan tutup tempat makan.

\section{b) Pengajaran Kedua}

Di pertemuan ini siswa akan diberikan permasalahan yang berkaitan dengan menghitung. Strategi siswa di perdiksi menggunakan HLT yang telah di revisi. Dalam sesi pertama siswa diminta untuk duduk dengan anggota kelompoknya masing-masing yang sama seperti pertemuan pertama, kemudian memberikan LAP 2.

Kemudian kegiatan yang pertama siswa diminta untuk bagaimana menghitung luas kebun bapak Budi dan Andi. Sebelumnya peneliti menyediakan gunting, lem dan kertas. Sebagian siswa menggunakan cara menghitung dan mengukur terlebih dahulu dengan penggaris guna menghitung luas kebun teh.

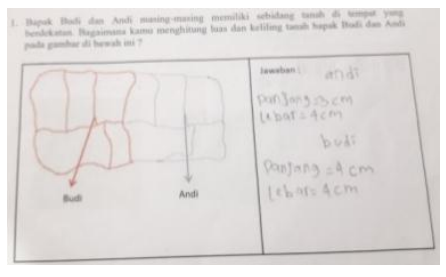




\section{Gambar 9. Jawaban Siswa pada LAP 2}

Dari pekerjaan diatas, jelas bahwa siswa mengukur dengan menggunakan penggaris area tanah kebun teh. Ini tidak sesuai dengan dugaan pada HLT : siswa akan menghitung kotak-kotak atau dengan tumpang tindih dan menghitung luas area yang tidak tertutupi. Setelah menghitung luas tanah siswa diminta untuk menghitung berapa banyak kertas origami yang diperlukan untuk menutupi seluruh area tutup tempat makan, siswa diminta untuk menghitung berapa banyak kertas origami yang diperlukan untuk menutupi seluruh area tempat makan.

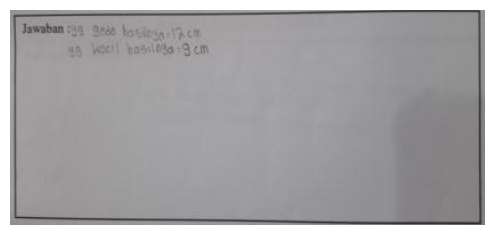

Gambar 10. Hasil Kerja Siswa

Gambar 10 membuktikan bahwa strategi atau cara yang digunakan kelompok 2 (mila) berbeda dengan kelompok 1. Mereka menggunakan cara dengan mengukur kertas origami sesuai dengan ukuran tempat tutup makan kemudian menempelkannya diatas permukaan tempat tutup makan hingga menutupi seluruh permukaan tempat tutup makan. Jawaban dari kelompok 2 tidak sesuai dengan dugaan HLT yang peneliti telah buat. Kemudian siswa diminta untuk menggambarkan tempelan kertas origami yang telah dibuat oleh kelompok lain, dengan begitu siswa akan melihat hasil kerja temennya dan secara langsung mereka akan menghitung satu persatu berapa banyak jumlah kertas origami yang digunakan kelompok temannya.
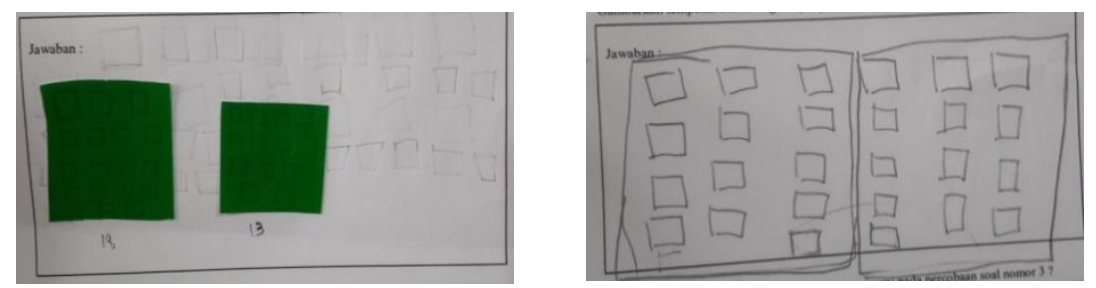

Gambar 11. Hasil Kerja Siswa

Hasil kerja siswa pada Gambar 11 memperlihatkan bahwa mereka memiliki strategi yang berbeda. Setelah itu siswa juga diminta untuk bagaimana cara mereka menghitung kertas origami yang telah mereka kerjakan pada soal nomor 3 .

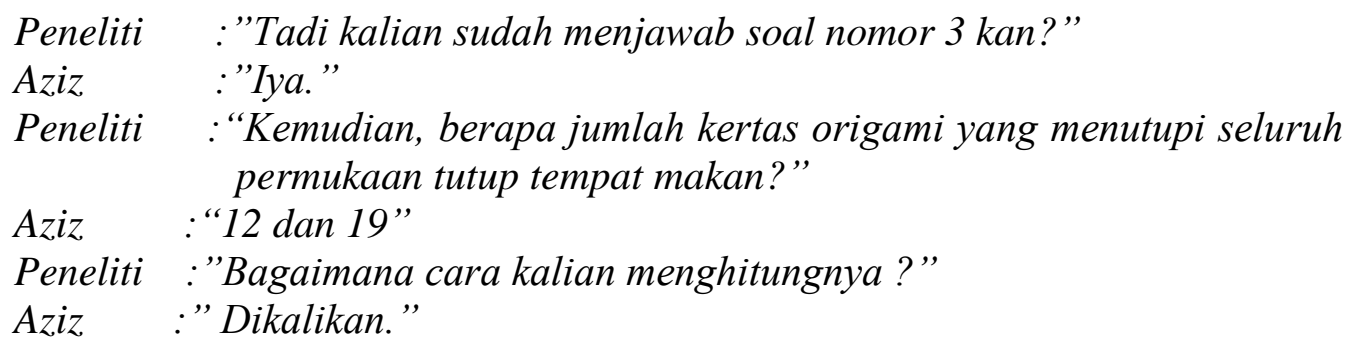




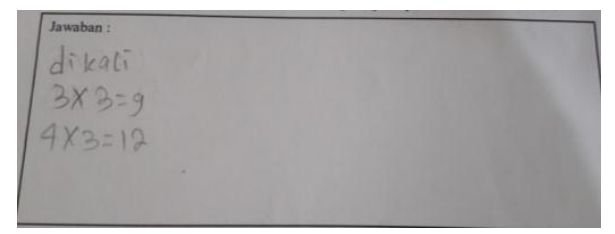

Gambar 12. Hasil Kerja Siswa

Dari percakapan dan Gambar 12 diatas terlihat bahwa mereka menghitung dengan dikali, yaitu jumlah origami baris diatas dikalikan dengan jumlah origami baris kebawah. Strategi mereka sesuai dengan dugaan HLT yang telah peneliti buat. Pada kegiatan LAP 2 ini siswa dapat menghitung berapa jumlah kotak origami dan luas area kebun teh, dapat disimpulkan bahwa mereka menemukan dengan dihitung satu persatu, kemudian ada yang dikalikan, namun untuk yang kebun the siswa menyelesaikan permasalahannyanya dengann cara dihitung menggunakan penggaris. Dengan strategi tersebut dapat membantu mereka dalam menghitung jumlah kotak origami dan luas area kebun the.

Hasil Analisis restropektif penelitian pada tahap pilot the experiment dan theaching experiment peneliti mendapatkan beberapa hasil yaitu pada tahap pilot the experiment siswa mengggunakan strategi dengan cara tumpang tindih, kemudian dengan tutup tempat makan mereka menggunakan kertas origami yang dipotong-potong dengan ukuran yang sama kemudian di tumpuk diatas permukaan tutup tempat makan hingga menutupi seluruh permukaan, mengukurnya menggunakan penggaris untuk membandingkan mana yang lebih besar dan menggunakan strategi penilaian dangkal (penilaian persepsi) dengan hanya melihat. Kemudian pada tahap teaching experiment tahapan learning trajectory nya berbeda dengan pilot the experiment dan sudah dijelaskan pada bagian peningkatan trajectory pembelajaran hipotesis, peneliti menggambarkan permasalah atau perumpamaan seperti peristiwa iceberg pada gambar dibawah ini:

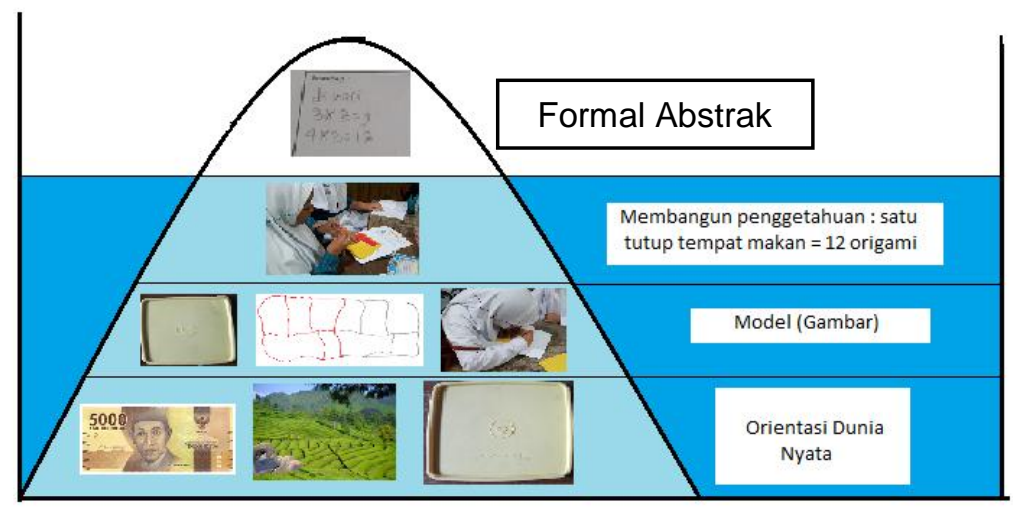

Gambar 13. Iceberg Pembelajaran Bangun Datar

Gambar iceberg di atas juga menunjukan bahwa untuk mencapai puncak gunung iceberg tersebut dibutuhkan tahapan-tahapan belajar yang cukup banyak supaya bisa sampai ke puncak gunung iceberg (bentuk formal matematika). Tahap pertama untuk mencapai puncak iceberg yaitu orientasi dunia nyata yang sering dilihat oleh siswa atau yang penah dilihat oleh siswa, misalnya tutup tempat makan dan kebun teh. Pada tahap selanjutnya siswa diajak untuk menggunakan 
model atau gambar yang memperesentasikan kedalam dunia nyata. Kemudian siswa dibimbing guna membangun penggetahuannya agar lebih abstrak. Model yang digunakan pada penelitian ini yaitu tempat tutup tempat makan dan kebun teh sudah dipresentasikan dalam menentukan pengukuran luas dengan melibatkan penggetahuan siswa dalam kehidupan sehari-hari atau dalam RME merupakan cara yang paling efektif untuk mencapai penggetahuan formal abstrak siswa.

Untuk itu pada tahap teaching experiment peneliti memberikan tahapantahapan pengejaran seperti fenomena iceberg dengan beberapa tahapan yaitu membandingkan, menggambarkan dan menghitung. Dengan begitu siswa akan menggetahui bahwa ketika mereka membandingkan kedua area kebun teh, menggambarkan kedua tutup tempat makan lalu menghitung mereka akan menggetahui luas dengan menggunakan startegi yang berbeda-beda disetiap kelompoknya. Hasil penelitian menunjukan bahwa penggunaan HLT dapat membantu menggetahui lintasan belajar peserta didik dalam memahami konsep pengukuran luas. Hal tersebut sejalan dengan berbagai penelitian yang menggunakan metode desain reseach telah dilakukan. Salah satunya yaitu Putri (2012) menggunakan metode desain reseach untuk meningkatkan pemahaman konsep. Dari hasil penelitiannya dapat disimpulkan bahwa penggunaan HLT dapat mengetahui lintasan belajar peserta didik dalam memahami konsep elastisitas. Asep (2019) penelitian dengan menggunakan metode design research yang didalamnya terdapat HLT tersebut dan menurutnya memegang peran sangat penting sebagai desain instrument penelitian. Menurut Asep (Fuadiah, 2017) istilah HLT tertuju kepada rencana pelaksanaan pembelajaran berdasarkan antisipasi belajar siswa yang mungkin akan dicapai dalam kegiatan proses pelaksanaan pembelajaran yang berdasarkan tujuan pembelajaran matematika yang diharapkan pada siswa, penggetahuan dan perkiraan tingkat pemahaman siswa serta pilihan aktivitaas secara matematis. Untuk itu daoat disimpulkan bahwa penggunaan pendekatan RME dengan menggunakan metode design reseach yang diberikan sudah dapat dikatakatan baik sebab sejalan dengan teori yang ada.

\section{SIMPULAN DAN SARAN}

Berdasarkan hasil penelitian dapat disimpulkan bahwa siswa dapat menyelesaikan masalah dengan berbagam macam strategi yang digunakannya melalui diskusi. Berdasarkan hasil penelitian tersebut, didapatkan lintasan belajar siswa pada materi bangun datar kelas IV B SDN Simpang Tiga Cilegon yang dapat membantu siswa mengenai pengukuran luas area. Kegiatan membandingkan area dapat memunculkan pemikiran siswa menggunakan strategi tumpang tindih. Siswa dapat memahami mengenai konsep pengukuran area melalui kegiatan tersebut. Pada penelitian kedua kegiatan membentuk kembali bidang persegi dan persegi panjang untuk menentukan luas dengan cara membandingkan, menggambarkan dan menghitung dengan cara menjiplak nya kemudian menutupi bagian atas permukaan dengan kertas orgimai yang dipotong-potong dengan ukuran yang sama lalu meletakannya diatas permukaan tutup tempat makan untuk mengukur luasnya. Pada saat siswa memahami startegi atau cara yang mereka temukan pada bidang pesergi dan persegi panjang, hal tersebut sangat bermanfaat bagi siswa karena lebih mudah mereka memahami. Implementasi RME pada Desain Pembelajaran, Krakteristik utama pada RME yaitu pembelajaran yang 
mengaitkan masalah dalam kehidupan sehari-hari mereka. Selama penelitian berlangsung, guru dan peneliti dapat berkomunikasi dengan baik dalam berdiskusi. Peneliti juga menemukan bahwa dengan menggunakan strategi atau cara dalam membandingkan, menggambarkan dan menghitung siswa dapat mengembangkan pemahamannya melalui kegiatan langsung untuk menentuka luas.

\section{DAFTAR RUJUKAN}

Budiyono, A., Kusumaningsih, W., \& Albab, I. U. (2019). Desain Pembelajaran Luas Lingkaran dengan Konteks Explore Dapur Berbasis Realistic Mathematics Education (RME) di Kelas VIII Sekolah Menengah Pertama (SMP). Jurnal Matematika dan Pendidikan Matematika, Vol. 1, 37-44.

Fuadiah, N. F. (2017). Hypotical Learning Trajectory Pada Pembelajaran Bilangan Negatif Berdasarkan Teori Situai Didaktis Di Sekolah Menengah. Jurnal Mosharafa, Vol. 6, 13.

Kadiyo. (2007). Bermain Dengan Matematika. Jakarta: Penerbit Anggota IKAPI.

Lisnani, R, I., \& Somakin. (2013). Desain Pembelajaran Bangun Datar Menggunakan Fable "Dog Cathes Cat" And Puzzel Tangram Di Kelas II SD. Kreano, Vol. 4, 11-25.

Sugesti, F. E., Budiyono, \& Subanti, S. (2014). Eksperimentasi Model Pembelajaran Kooperatif Tipe Structured Numbered Heads (SNH) Dan Two Stay Two Stray (TSTS) Dengan Pendekatan Realistic Matheamtics Education (RME) Pada Prestasi Belajar Matematika Ditinjau Dari Adversity Quotient (AQ) Siswa. Jurnal of Mathematics and Mathematics Education, Vol.4, 1-10.

Sutisna, A. P., Maulana, \& Subarjah, H. (2016). Meningkatkan Pemahaman Matematis Melalui Pendekatan Tematik Dengan RME. Jurnal Pena Ilmiah, Vol. 1, 33.

Tarigan, D. (2006). Pembelajaran Matematika Realistik. Jakarta: Departement Pendidikan Nasional Direktorat Jendral Pendidikan Tinggi.

Trianto. (2009). Mendesain Model Pembelajaran Inovatif-Progresif. Jakarta: Kencana. 